\title{
Geophysical Contribution in the Characterization of Deep Water Tables Geometry (Sidi Bouzid, Central Tunisia)
}

\author{
D. Khazri and H. Gabtni \\ Laboratoire Géoressources, Centre de Recherches et des Technologies des Eaux (CERTE), Technopôle Borj-Cedria, \\ BP 273, 8020 Soliman, Tunisia \\ Correspondence should be addressed to D. Khazri; dadou-cosmos@live.fr
}

Received 23 September 2014; Accepted 16 December 2014

Academic Editor: Rudolf A. Treumann

Copyright (C) 2015 D. Khazri and H. Gabtni. This is an open access article distributed under the Creative Commons Attribution License, which permits unrestricted use, distribution, and reproduction in any medium, provided the original work is properly cited.

Geophysical data combined with geological and hydrogeological data were analyzed to characterize the geometry of Oued El Hajel and Ouled Asker deep water tables (Sidi Bouzid). The obtained results allowed refining the geostructural schema by highlighting the individualization of the NE-SW underground convexity of Ouled Asker and the anticline of axis Es Souda-Hmaeima and Ezaouia on either sides of two hydrogeological thresholds. The geometrical analysis determined the spatial extension of Ouled Asker and Oued El Hajel subbasins. The seismic cartography of semideep and deep reservoirs (Oligo-Miocene; Eocene and upper Cretaceous) associated with the main subbasins contributed to proposing hydrogeological prospect zones for a rationalized groundwater exploitation.

\section{Introduction}

Agricultural development and rapid population growth contributed to an increasing demand for water resources. Consequently groundwater became a vital necessity in the Sidi Bouzid governorate in central Tunisia. This area is characterized by a semiarid to arid Mediterranean climate with irregular annual rainfall that does not exceed $350 \mathrm{~mm} /$ year and long periods of drought [1].

The Sidi Bouzid water table is one of the most important aquifers in Tunisia. However, the overexploitation of this aquifer requires a reassessment of deep water resources. Among these deep aquifers those of Oued El Hajel and Ouled Asker are of an ultimate interest. They are lodged into narrow NE-SW Atlasic synclines [2], situated near to Jebel Es SoudaHmaeima on the eastern border of the Tunisian Mountains between the Atlasic block to the west and the Pelagian block to the east (Figure 1). The Jebel Es Souda-Hmaeima is a rather short Atlasic anticline which could be compared with a dome. According to Tanfous et al. [3] it is a "back folded anticline" affected by kilometric faults oriented NS, NW-SE, and EW [4].
In the present study, the characterization of Oued El Hajel and Ouled Asker water tables was developed and applied to deeper aquifers through the combination of geophysical, tectonic, and hydrodynamic data.

A detailed geometrical characterization of these subbasins by geophysical methods will limit each deep water table and help image the geometry of these aquifers such as the gravity survey method. In this study, gravity was selected in order to give a regional picture of the subsurface geology before making extensive surveys by the seismic reflection method.

For a better use of these deep aquifers and a rationalization of the future groundwater exploration in the arid area of central Tunisia, prognostic wells were realized based on seismic mapping and the estimation of water reservoirs depths.

\section{Geological and Hydrogeological Setting}

Geophysical and hydrogeological studies consist of an integration between modern geophysics and conventional methods (rainfall, piezometric, lithology, hydrodynamics...). To 


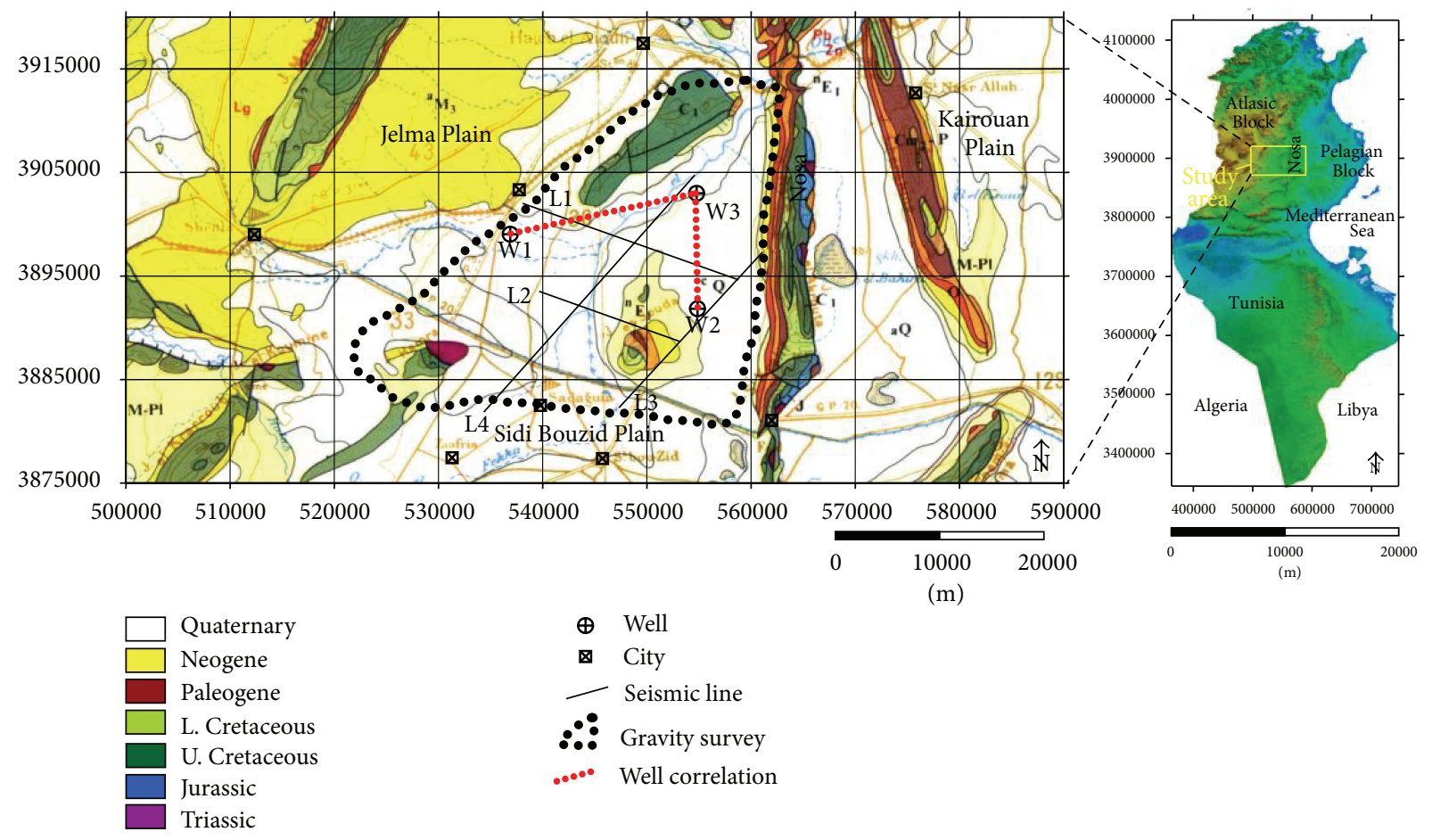

FIGURE 1: Location of the study area and the used geophysical data on the geological and structure map of central Tunisia [16].

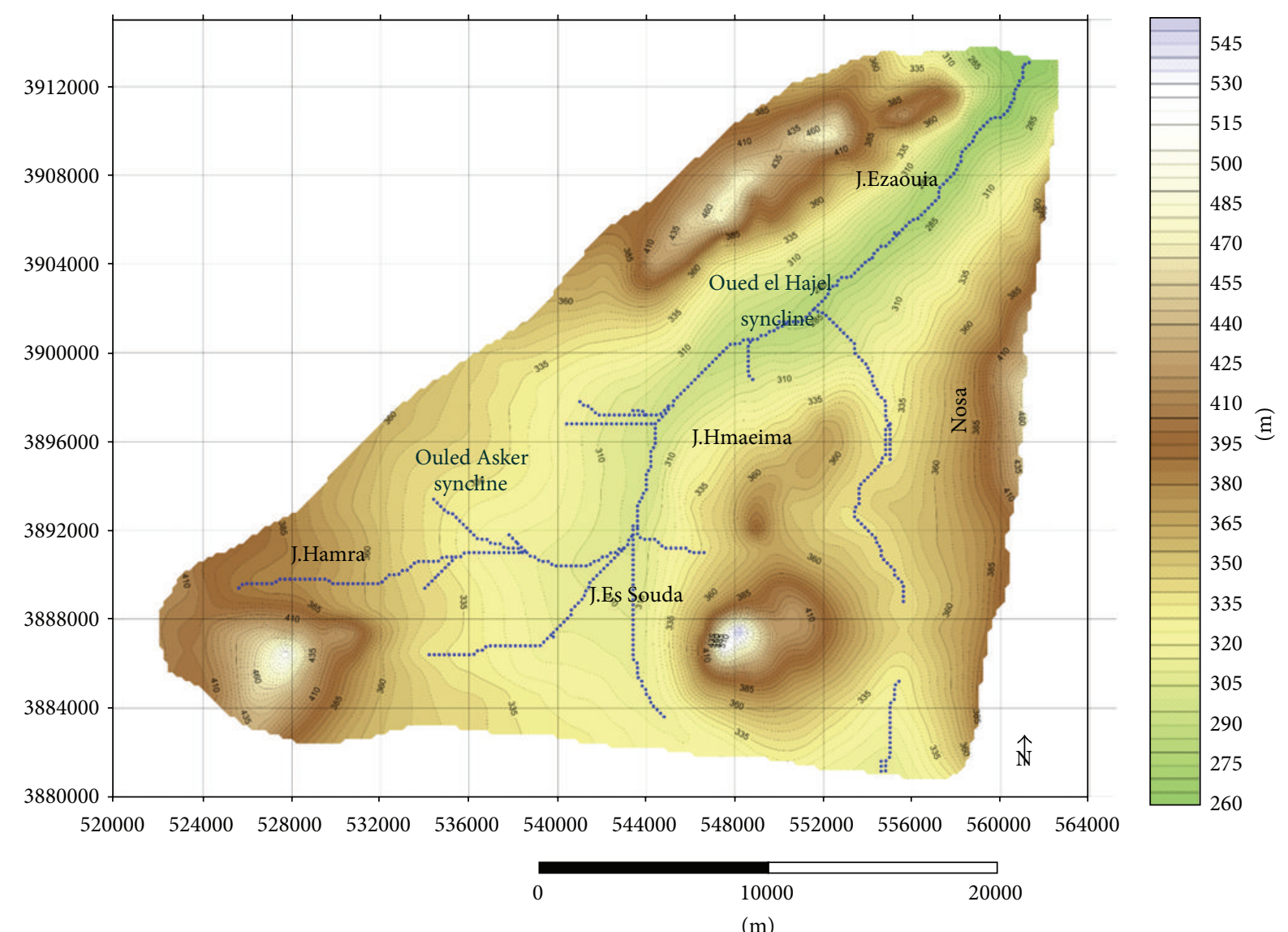

FIGURE 2: Topographic map of the study area. 


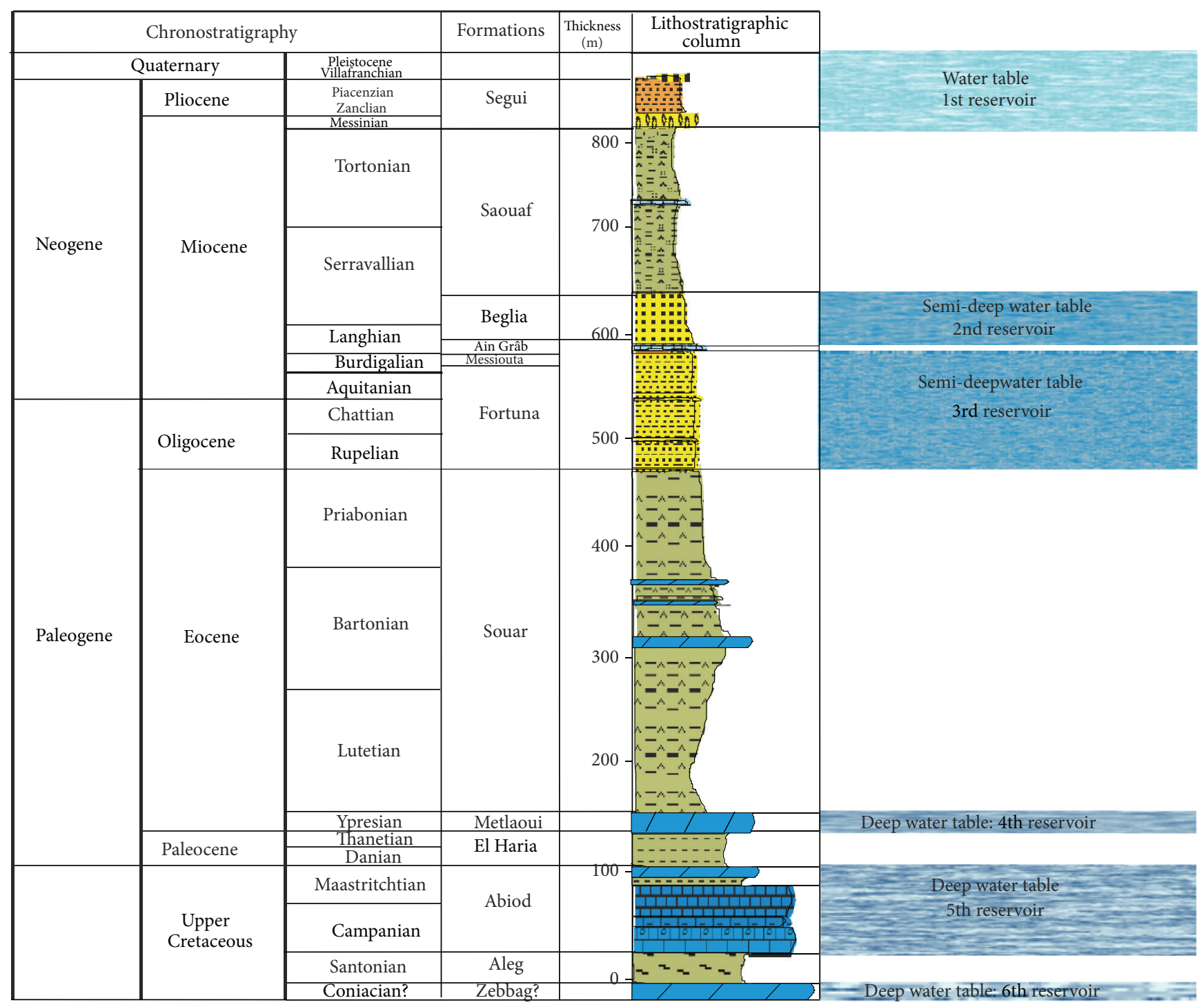

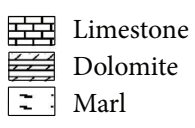

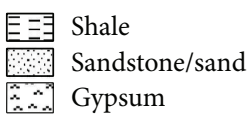

Figure 3: Lithostratigraphic column of Jebel Es Souda modified from [17]. define the hydrogeological setting of the study area, a topographic map covering the Jebel Es Souda and its surroundings has been presented (Figure 2). The altitude varies between $260 \mathrm{~m}$ and $555 \mathrm{~m}$. Jebel Es Souda-Hamaeima $(540 \mathrm{~m})$ is bordered to the north by Jebel Ezaouia, to the east by the $\mathrm{N}-\mathrm{S}$ axis and Oued EL Hajel syncline, to the west by Ouled Asker syncline and Jebel Hamra, and to the south by the Kebar massif. The drainage system in this area is mainly characterized by the dominance of Oued El Hajel and its affluents [1].

Oued El Hajel and Ouled asker deep water tables belong to a zone characterized by a multiphase tectonic regime. The most important movements that affected this area were mainly compressive and extensional events [5] controlled by megafaults oriented NE-SW, N-S, and NW-SE. The main aquifers associated with these deep water tables can be recognized and described in the flank of Es Souda-Hmaeima anticline (Figure 1). Oued El Hajel syncline is limited to the NNW by the anticline of Ezaouia-Roua, the N-S axis to the East and Jebel Es Souda, and the Kasserine fault to the South. The aquifers corresponding to the Oued El Hajel syncline are mainly made of Mio-Pliocene and Quaternary sandstone. Its thickness varies from $1000 \mathrm{~m}$ to $1150 \mathrm{~m}$ : the first reservoir level reaches a depth of $100 \mathrm{~m}$ and it consists of a shallow Quaternary water table formed by an alternation of sands and clays. The second reservoir refers to a semideep water table and it is mainly made of Oligo-Miocene sand and sandstone. Its depth varies between $600 \mathrm{~m}$ and $800 \mathrm{~m}$. The Miocene 


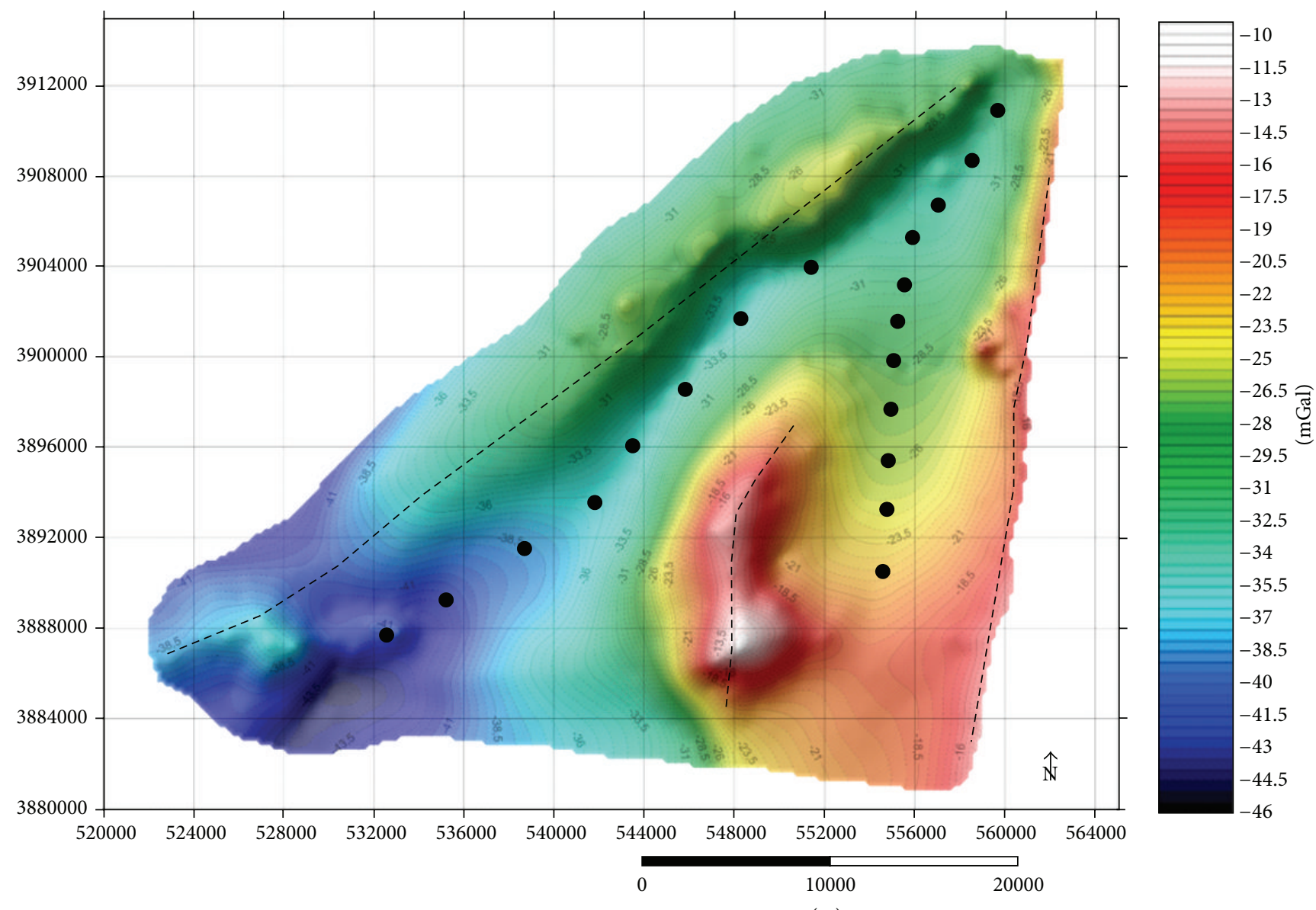

(m)

- - - High gravity axis

$\bullet$ Low gravity axis

FIGURE 4: Bouguer gravity map of the study zone showing the positive and the negative trends of the anomaly.

sandstones are characterized by an annual exploitation value of $0,86 \mathrm{Mm}^{3} /$ year with a continuous fictitious debit of $27,4 \mathrm{~L} / \mathrm{s}$ and a global salinity that reaches $3,90 \mathrm{~g} / \mathrm{L}$. It must be mentioned that the Upper Cretaceous carbonates were reached in a depth of $1150 \mathrm{~m}$ in the Garaât Ben nour hydrolic well and are considered as the deepest aquifer of the Oued El hajel water table (W3, Figure 1).

The Ouled Asker water table is a part of Ouled asker syncline which is bordered by the anticlines of Jebel Mghila to the North-West, Jebel Labaiedh to the North, and Jebel Ezaouia to the North-East and to the south by Jebel Hamra. It is a multilayer aquifer system containing Pliocene-Quaternary shallow aquifers that reach $40 \mathrm{~m}$ of thickness. Semideep aquifers are also present in this area and they are made of Oligo-Miocene sand and sandstone. The deepest aquifers of this water table are mainly made of Upper Cretaceous-lower to middle Eocene carbonate.

The aquifers of Oued El Hajel and Ouled Asker deep water tables are made of Beglia formation (Langhian-Serravallian), Ain Grab formation (Langhian), Fortuna formation
(Oligocene), Metlaoui (lower Middle Eocene), and Abiod formations (Campanian- Maastrichtian) (Figure 3).

\section{Material and Methods}

3.1. Gravity Data. The gravity data that has been used for the current study were obtained from the Office National des Mines (ONM). The free-air and Bouguer corrections were made using the sea level as reference and the average density was fixed to $2.4 \mathrm{~g} / \mathrm{cm}^{3}$. In order to elaborate the complete Bouguer map of the zone, a grid was performed using the gravity data with a spacing of 1 point per $\mathrm{Km}^{2}$.

3.2. Seismic Data. The seismic acquisition in the study area was conducted by the General Geophysical Company (GGC) for the benefit of the "Union Texas Tunisia" company in the region of Kasserine from March to August 1981. Four seismic lines L1, L2, L3, and L4 were analyzed and interpreted in this work. The latter crosses the main structures of the study area such as Oued El Hajel and Ouled Asker synclines which contain the target deep water tables (Figure 1). 


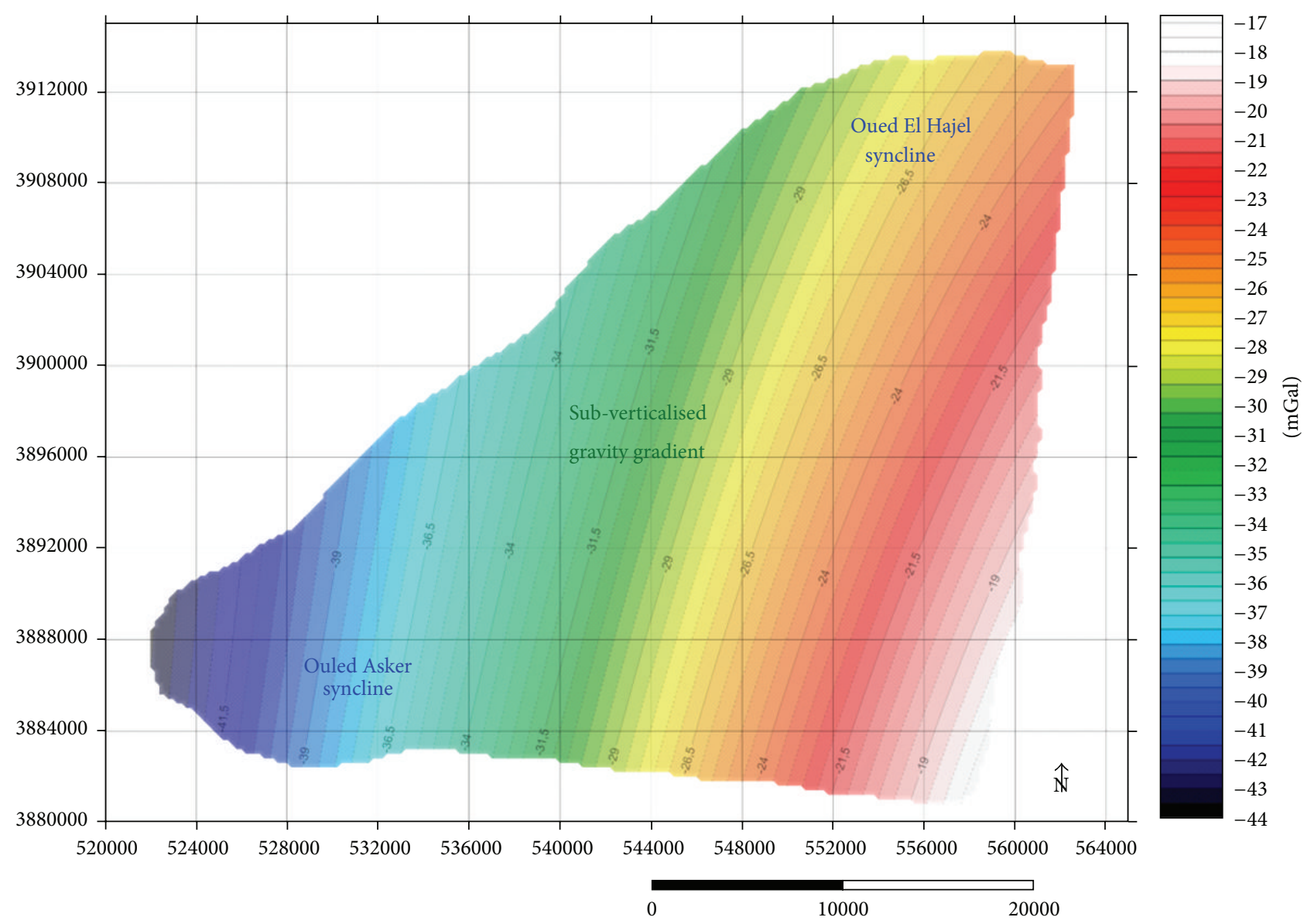

(m)

FIGURE 5: Regional gravity anomaly map of the study area.

\section{Results and Discussions}

\subsection{Gravity Analysis}

(i) Bouguer and Residual Gravity Maps. Based on the gravity data, a Bouguer gravity map was performed in which the gravity anomaly varies between $-46 \mathrm{mGal}$ and $-10 \mathrm{mGal}$ (Figure 4). The study area shows a structural complexity illustrated through different gravity axes: a negative gravity axis to the extreme west and a positive gravity axis to the extreme east. This is related to the thinning of the earth's crust in Tunisia that was proved by the deep seismic refraction company Geotraverse EGT85 [6].

These anomalies are separated by accentuated gravity gradients that indicate the presence of several discontinuities in the subsurface. These discontinuities are controlling the geometries of the different structures in this study area. The Bouguer gravity map illustrated in Figure 4 shows the subsurface structural complexity. Several structures are defined such as anticlines, synclines, major faults, and Triassic outcrops. The principal anomaly axes are illustrated as follows from the west to the east. (a) The first NE-SW positive anomaly axis goes to $-33 \mathrm{mGal}$ and it corresponds to Jebel Hamra and Jebel Ezaouia.

(b) The second N-S to NNE-SSW positive axis reaches $-18 \mathrm{mGal}$ and it corresponds to Jebel Es SoudaHmaeima.

(c) The third N-S positive axis corresponds to the N-S axis lineaments and it reaches $-13 \mathrm{mGal}$.

The principal negative gravity axes are from the west to the east as follows (Figure 4).

(a) A first NE-SW negative gravity axis delineates the Ouled Askar syncline and it reaches $-46 \mathrm{mGal}$.

(b) The second negative axis reaches $-31 \mathrm{mGal}$ with a $\mathrm{N}$ $\mathrm{S}$ to NNE-SSW major direction and it corresponds to the Oued El Hajel syncline.

Several upward continuations were performed based on the Bouguer gravity grid of the studied area. At a depth of $8000 \mathrm{~m}$ we notice the persistence of particular anomaly sources which are considered as the deepest and most rooted. 


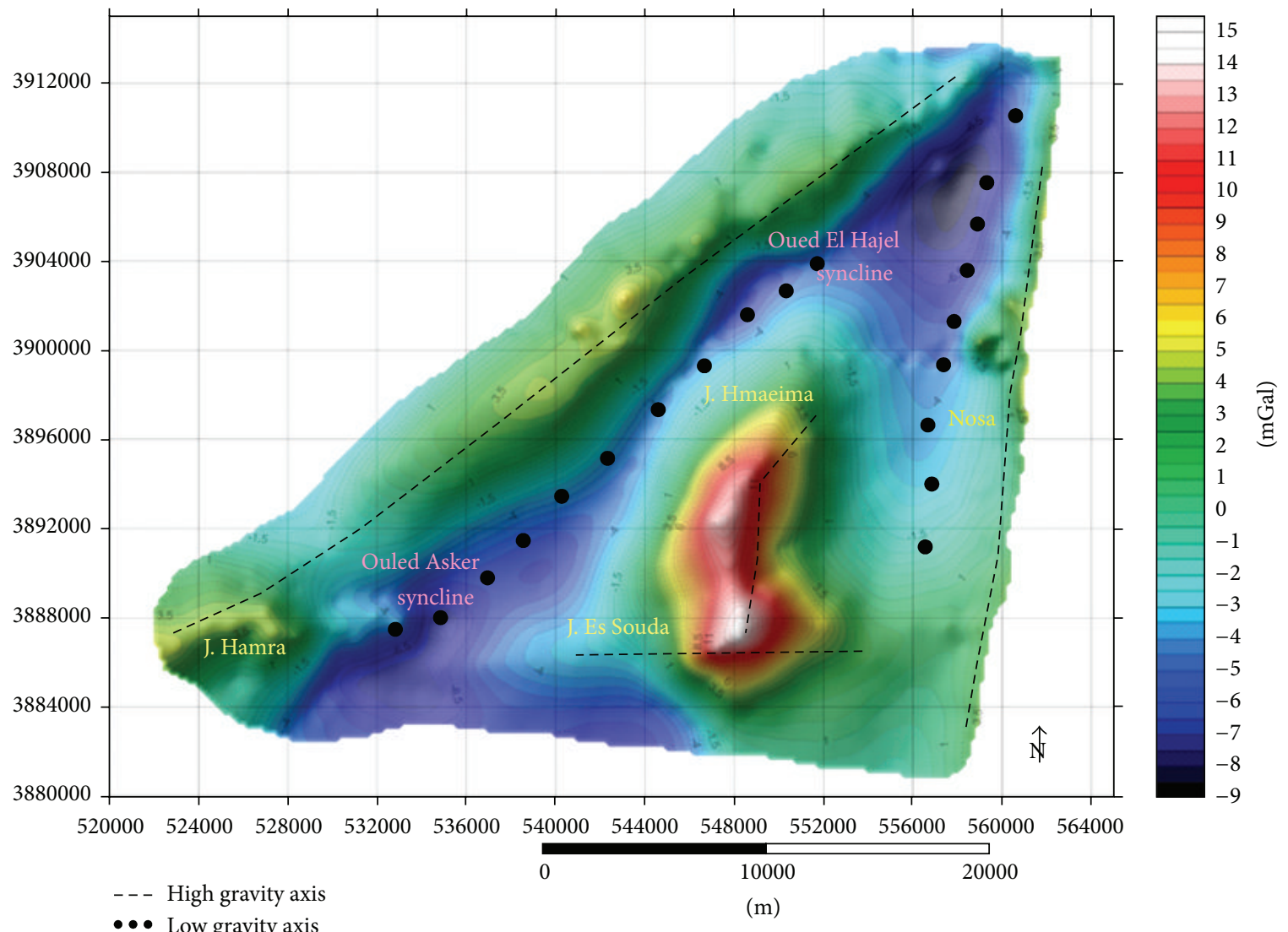

FIgURE 6: Residual gravity map of the study zone.

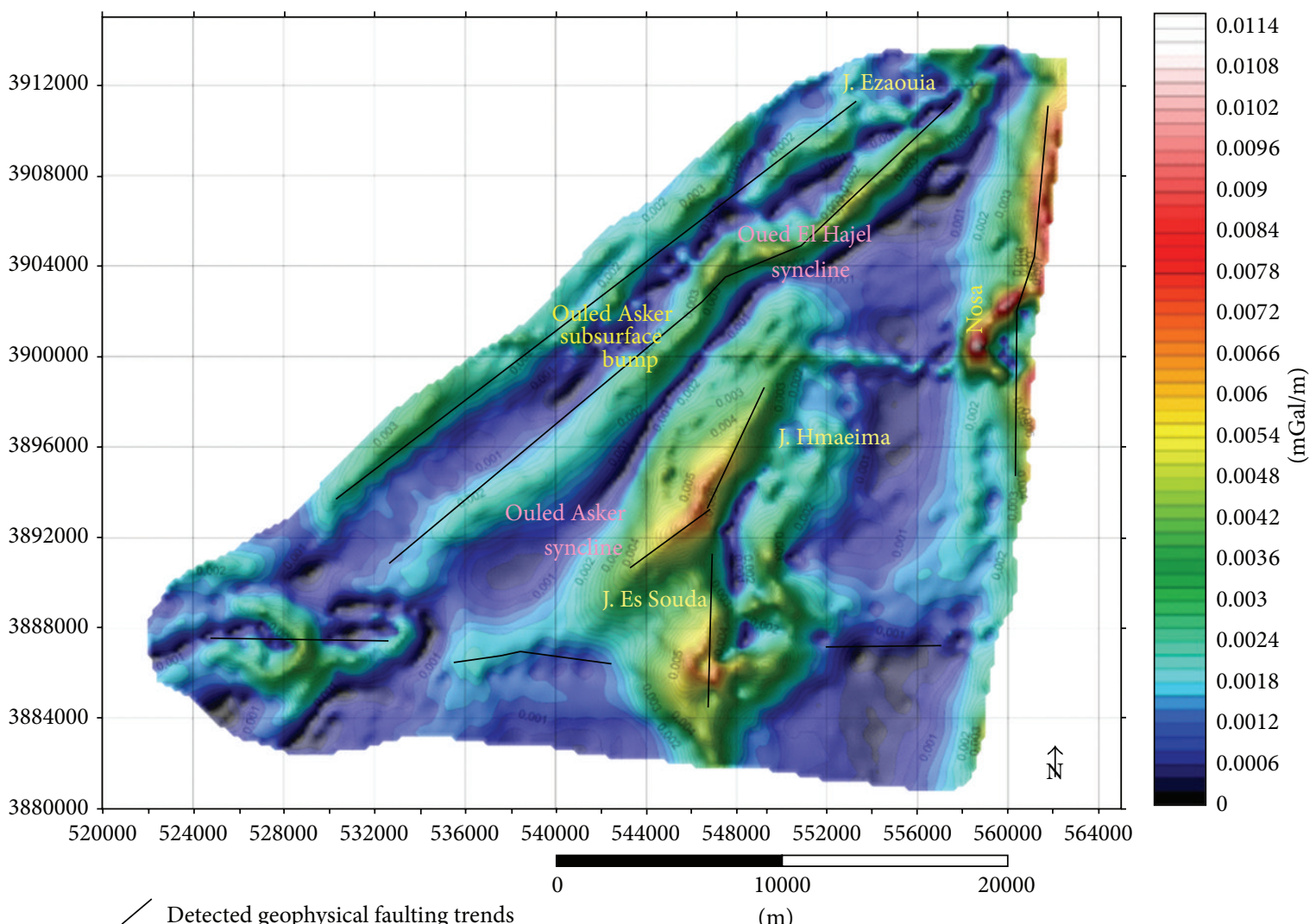

FIGURE 7: The structural lineaments after the horizontal gradient gravity magnitude map (HGGM). 

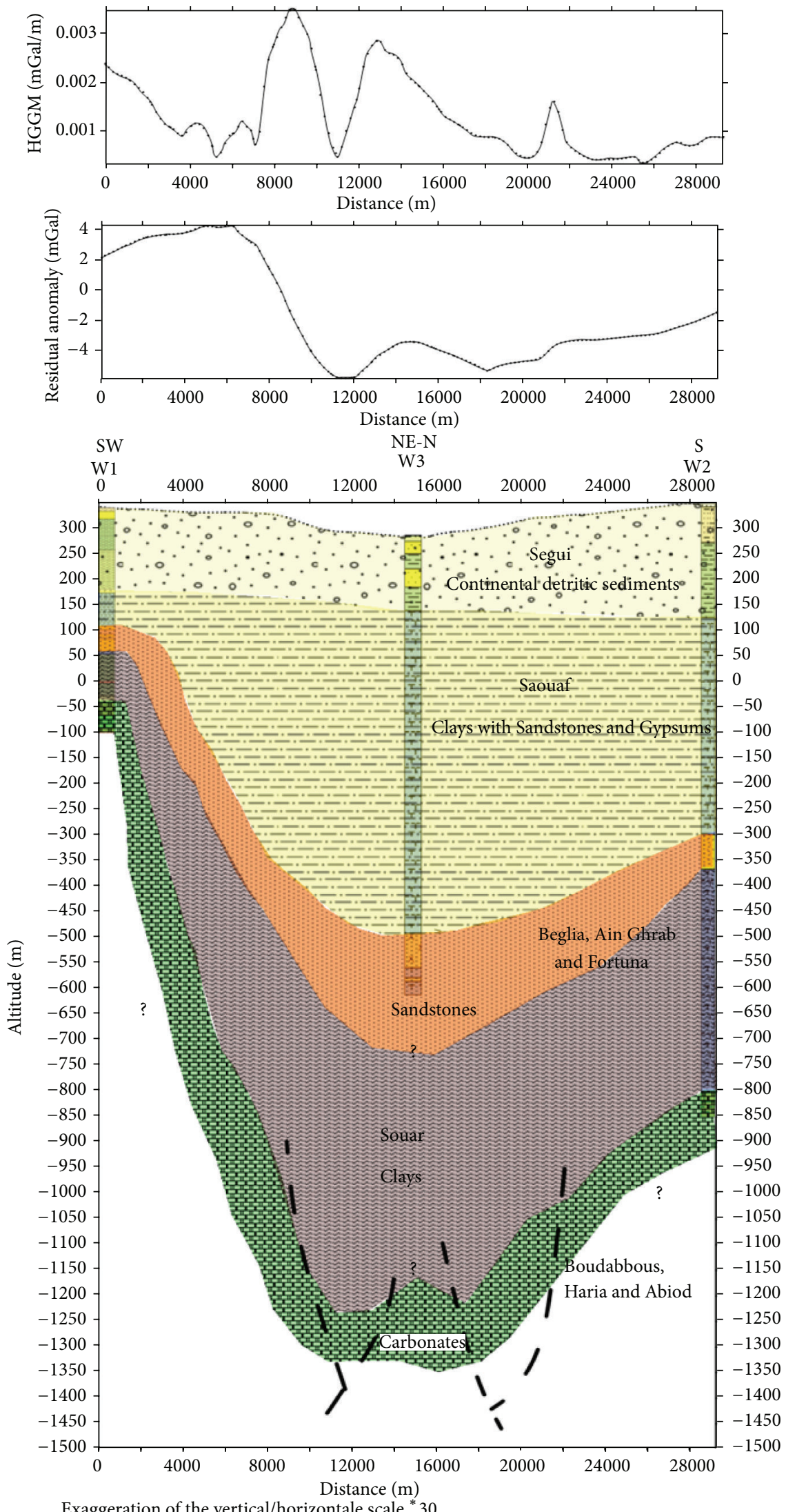

FIGURE 8: Subsurface structure of the study area using a hydrostratigraphic cross sections linking hydraulic well (W1, W2, and W3), horizontal gradient gravity magnitude, and residual gravity anomaly profiles. 


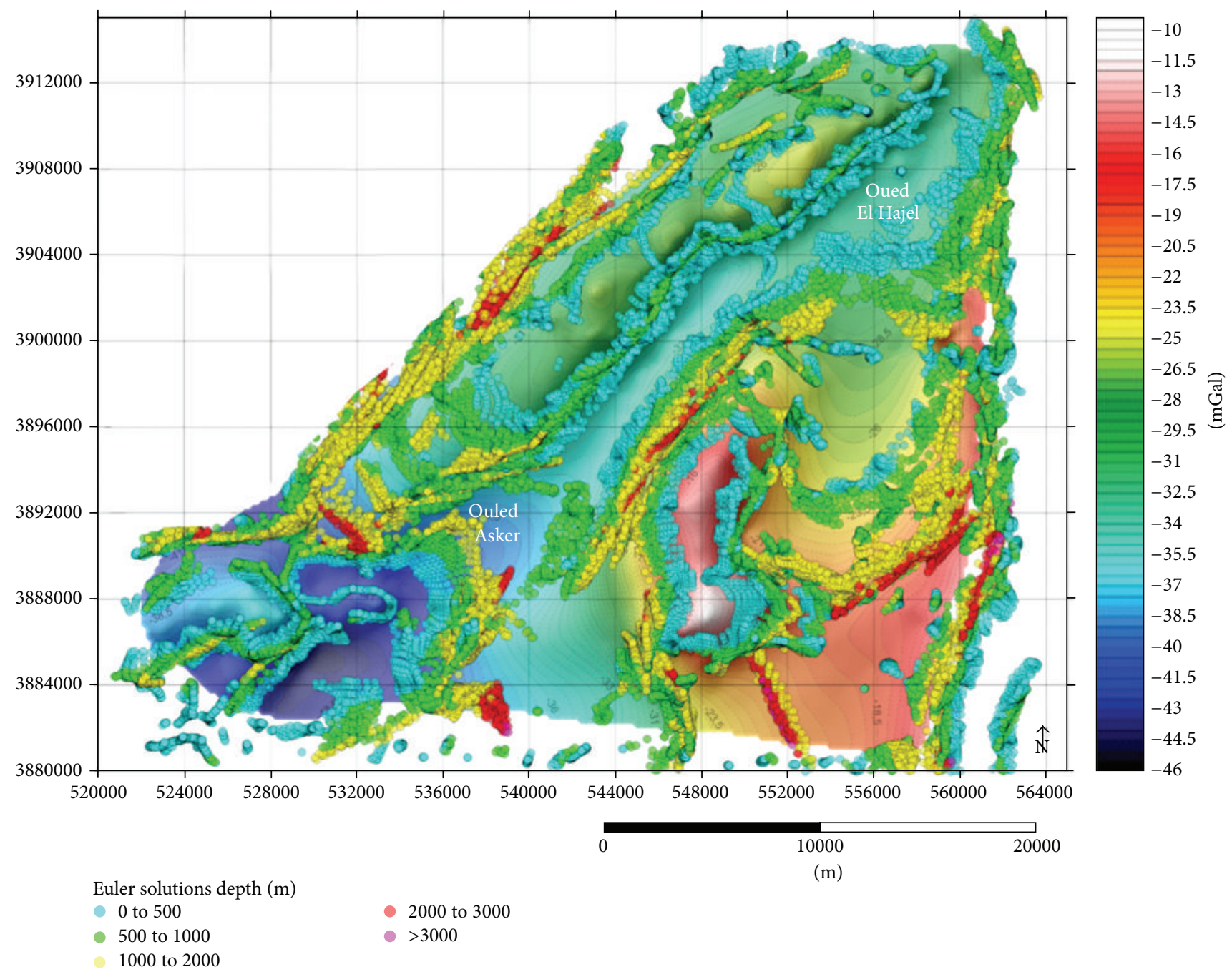

Figure 9: Euler solution to detect contact zone (structural index 0, window $10 * 10$, and error $15 \%$ ).

Also a gravity gradient was identified separating both the negative and the positive anomaly axes which are almost vertical, and isogal curves were well drawn. Thus, the regional gravity maps were chosen (Figure 5). The gravity gradient observed in the regional gravity map delineates two gravity domains: (1) a positive domain corresponding to the Jebel Es Souda-Hmaeima due to the deep structures affecting the ante-Triassic levels; these results confirm those determined by Tanfous et al. [3], and (2) a negative domain covering the Ouled Asker syncline with persistence of a less important negative anomaly (Oued El Hajel).

Therefore the regional gravity anomaly will be subtracted from the Bouguer gravity anomaly in order to obtain the residual gravity map (Figure 6). The emplacement of the different gravity anomalies on this map coincides with the different geological lineaments determined in the surface. The anomaly values vary from -9 to $15 \mathrm{mGal}$ and the major anomaly axes are NE-SW and N-S to NNE-SSW (Figure 6).

(ii) The Horizontal Gravity Gradient Magnitude Map (HGGM). The performance of the horizontal gravity gradient magnitude map will allow us to trace the emplacement of the different anomaly sources and causative bodies [7]. In fact, this map highlights the different faulting systems affecting the study area for a better understanding of the structural and tectonic movements that affected the zone.

The major lineaments and principle accidents affecting the Jebel Es Souda-Hmaeima and its neighboring structures will be highlighted using the HGGM map. These accidents affect the different hydrogeological reservoirs and water tables of Ouled Asker and Oued El Hajal according to two main directions: a first NE-SW to NNE-SSW direction associated with Jebel Hamra-Jebel Ezaouia, to Jebel Es SoudaHmaeima, and to the underground bulge of Ouled Asker. A second N-S main direction associated with the N-S axis and the southern part of Jebel Es Souda. Other minor E-W directions were also recorded (Figure 7).

For a better subsurface architecture visualization of this area, gravimetric profiles such as the HGGM and the residual gravity anomaly were performed and coupled along with a hydrostratigraphic section. The latter was obtained by 

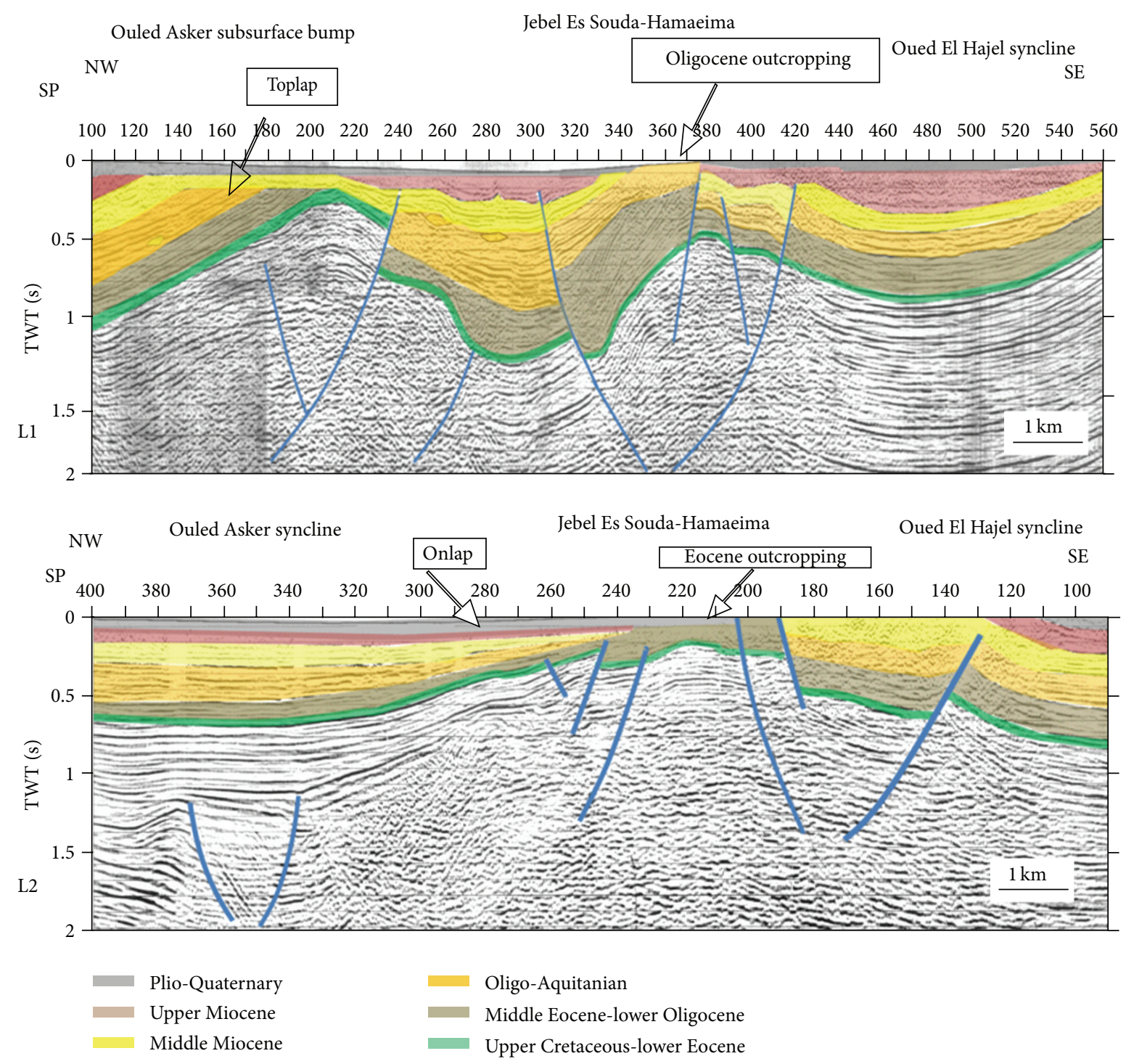

FIGURE 10: Interpreted seismic lines across the study area (L1 and L2).

correlating the hydrologic wells W1, W2, and W3 (Figure 1) in order to affirm the existence of faults affecting the Oued El Hajel and Ouled Asker basins.

The hydrostratigraphic section (Figure 8) illustrates the lateral variation of the different geologic units and it confirms the results earlier determined through the gravimetric profiles. In fact, it shows horst and graben structuring affected by normal and inverse faulting systems. This will be better explained and illustrated in the seismic study of this area.

(iii) Estimation of the Euler Solutions. The Euler deconvolution is a geophysical technique that consists of a qualitative and a quantitative analysis of gravity data. It highlights the main discontinuities affecting the region in the subsurface in order to detect the contact zone affecting the hydrogeological reservoirs [8]. The deepest accidents detected are of NE-SW and N-S directions with depth values reaching the $3500 \mathrm{~m}$. Using this method it was also possible to confirm the presence of N-S fault corridor (Figure 9) to the west of the N-S axis $[9,10]$ and continues to the south to Sebkhat Enoual near Meknassy-Mezzouna [11]. Other NE-SW lineaments were detected over the Ouled Asker bulge with depth values going from $2000 \mathrm{~m}$ to $3500 \mathrm{~m}$. These lineaments separate the subbasins of Ouled Asker and Oued El Hajel.

4.2. Seismic Analysis. The different seismic profiles were calibrated and interpreted using previous studies [12-15], outcrop data, field geology and also by an interpolation with the neighboring hydraulic wells. The results of those interpretations were used to locate the seismic horizons susceptive of being the most important aquifers in the study area such as the following:

(i) the carbonate horizons of the Abiod formation (Campanian-Maastrichtian) and the Metlaoui formation (Ypresian); 

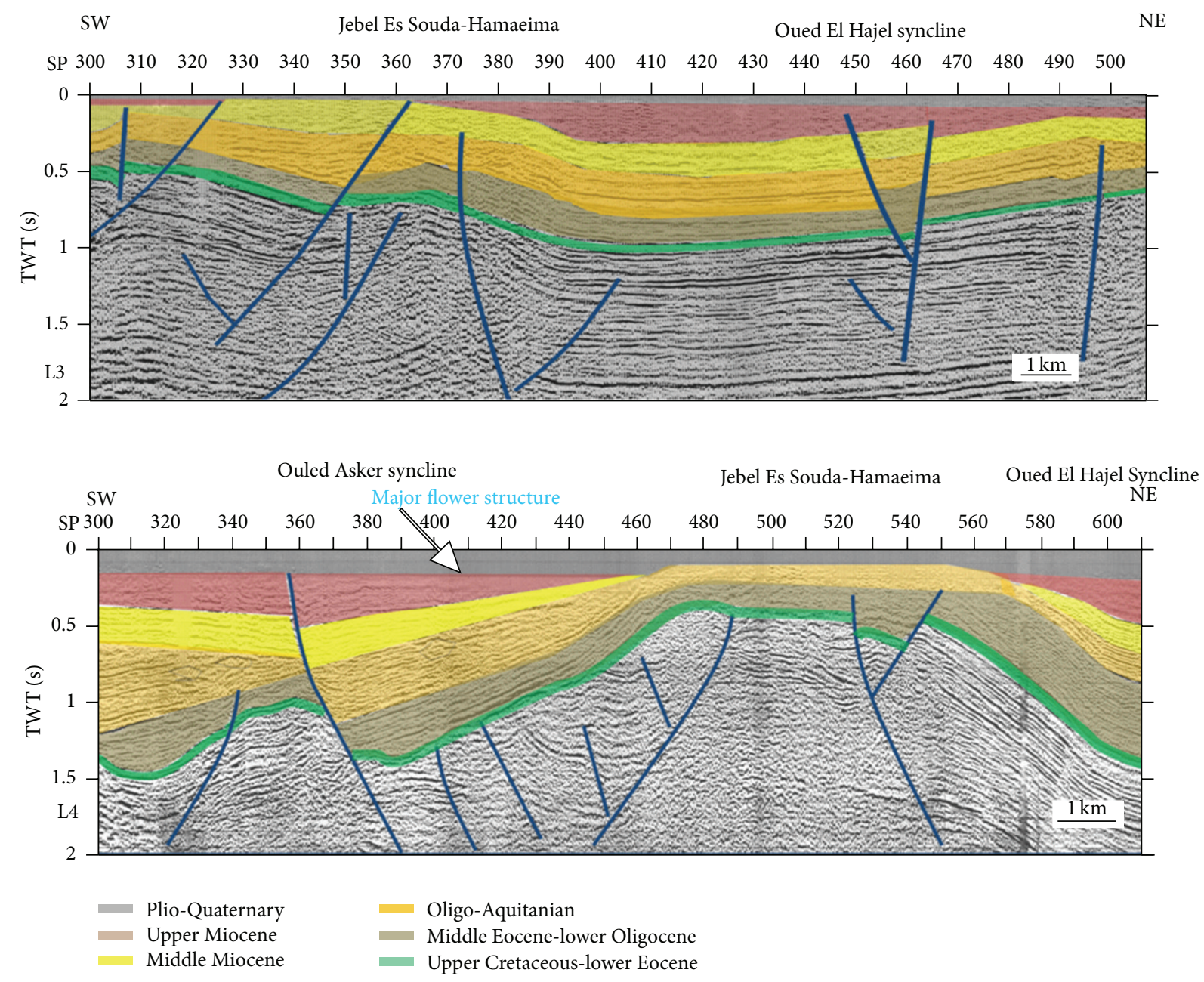

FIGURE 11: Interpreted seismic lines across the study area (L3 and L4).

(ii) the sandstone horizon of the Oligocene Fortuna formation;

(iii) the sandy and conglomeratic Middle Miocene (Langhian-Serravallian) horizons of the Beglia formation.

(i) The First Seismic Line (L1). It consists of a NW-SE seismic section crossing the Jilma-Ouled Asker basin and Jebel Hmaeima structure and reaches the Oued El Hajel syncline. The North western part of this seismic section shows intense fracturing of the different geologic units that delineates elevated and collapsed zones. This tectonic regime affected the flanks of the different anticlines in the area. The latter was the result of successive compressive phases (Upper Cretaceous-Eocene; Miocene until Villafranchian phase).

In this seismic section, box folds are identified as well as tilted blocks due to a set of major listric faults. Significant negative flower structures were recognized in the area resulting from grafting of second order faults on the major listric faults mentioned previously. Also horst and graben system were associated with this tectonic set. In the South eastern seismic line part, a decrease in the intensity of fracturing and thickening of geological layers is noted. Also an important gutter structure covering the Oued El Hajel syncline which is a basin marked by an intensive subsidence was identified (Figure 10, L1).

(ii) The Second Seismic Line (L2). To the North-west of this profile a gutter structure is individualized corresponding to Ouled Asker syncline, which is bordered to the west by the bulge of Ouled Asker limiting the extent of this basin as compared to Oued El Hajel syncline. To the SE, the sedimentary series are beveled marking the thinning of geological layers in this area (Figure 10. L2).

(iii) The Third Seismic Line (Line L3). The South western part of this seismic section is marked by oblique to subparallel configuration and also by a thinning of geological layers marking the transition from a subsident domain occupied by Oued El Hajel syncline to a folded domain. Several popup structures (at the 370 shot point) mark this domain resulting from the action of listric faults uplifting the central compartments and sinking those borders (Figure 11, L3). 


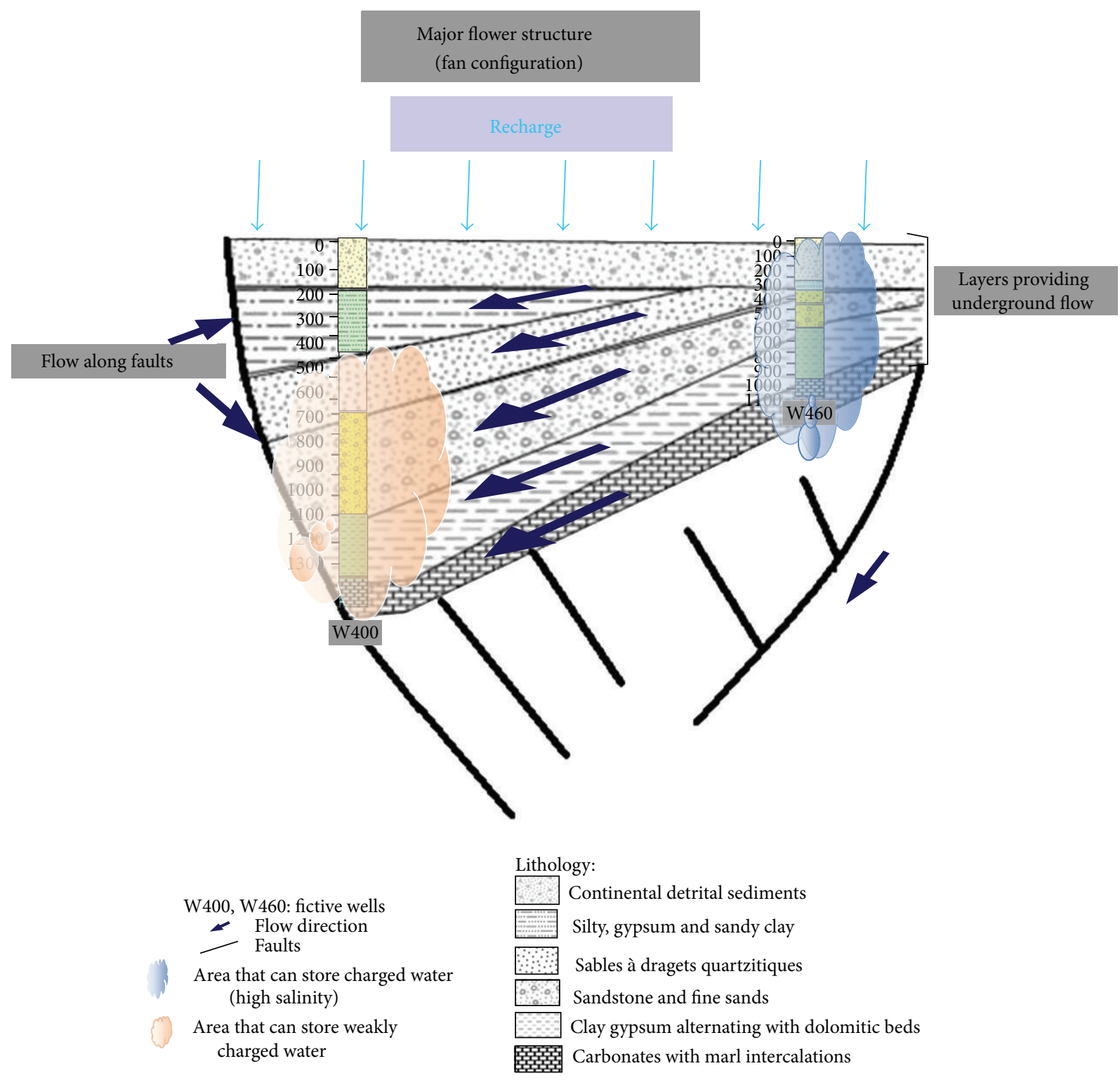

FIGURE 12: Hydrogeological sketch of Ouled Asker basin with W400 and W460 fictive wells.

(iv) The Fourth Seismic Line (L4). The South western part of this seismic section is noticeable; it is characterized by a fan configuration related to a negative flower structure in the center of Ouled Asker syncline previously detected in the first seismic line. In this structure the sedimentary series mark a significant thickening as compared to the Es Souda anticline flank (Figure 11, L4). This flower structure is of a particular hydrogeological interest regarding its geometry and its groundwater flow direction. In addition, this structure provides a vertical groundwater flow supplying the deep aquifers of the region through the permeable layers and the deepest faults. After being confined the deep geological layers in the center of Ouled Asker basin can accumulate highly saline water (charged water), while, in the edges of the basin and to shallower depths, the water is less charged and the flow is said transient (Figure 12).
Interval velocities calculated using the Dix formula (1955) were adopted, and profiles of average velocities were established for both lines 3 and 4 to estimate the depths of target aquifers and to provide several fictitious well (L3: W380; W480 and L4: W400; W460) in the center and edges of Oued El Hajel and Ouled Asker basins facilitating the exploitation of the main deep aquifers in this study (Figures 13 and 14).

Concerning the third seismic line L3 and after the distribution of depths relative to the average velocities, at a double time from $0.8 \mathrm{~s}$ to $1 \mathrm{~s}$, the Upper Cretaceous is characterized by a velocity variation from $2700(\mathrm{~m} / \mathrm{s})$ to 3030 $(\mathrm{m} / \mathrm{s})$ for depths up to $1215 \mathrm{~m}$ and at a less important double time from $0.3 \mathrm{~s}$ to $0.5 \mathrm{~s}$, the velocities variations extend from $1600(\mathrm{~m} / \mathrm{s})$ to $2000(\mathrm{~m} / \mathrm{s})$ with depths ranging from $387 \mathrm{~m}$ to $520 \mathrm{~m}$. It is also noted that the change in average velocities is proportional to the lateral variation of sedimentary sequences 


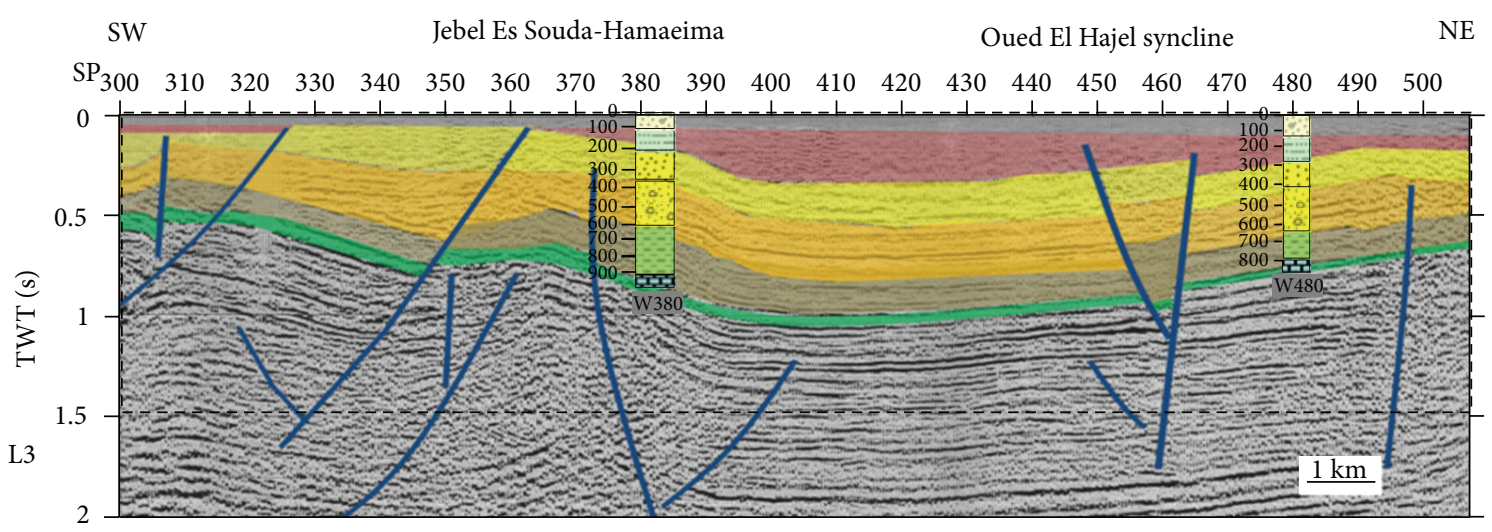

(a)

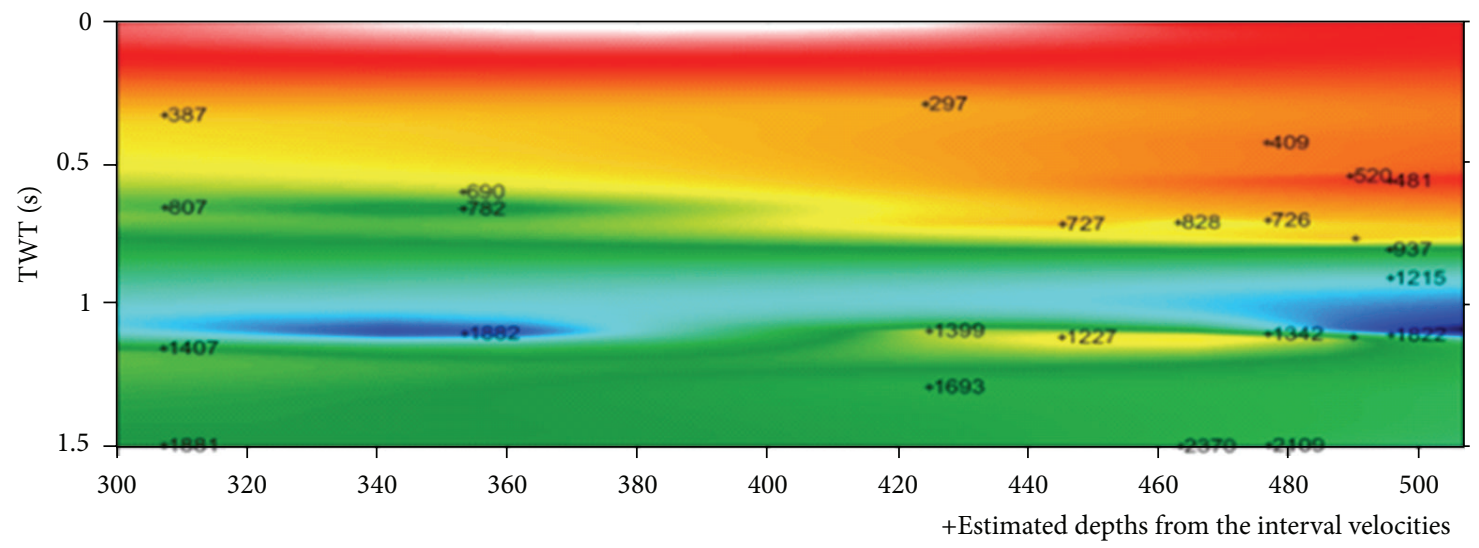

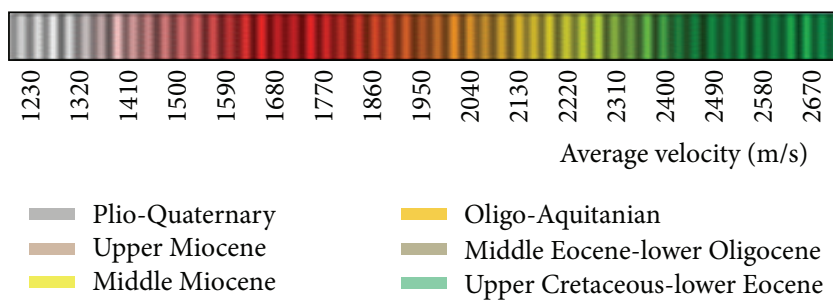

(b)

Figure 13: (a) W380 and W480 fictive wells associated with the L3 seismic line and (b) average velocity variation associated with L3 (black dashed line frame). (+) Depths estimated from the interval.

being structured in moderately folded to the SW higher areas, against sunken, and subsidence areas to the NE corresponding to the Oued El Hajel gutter (Figure 13). This structure has been confirmed by seismic mapping tool Isochronous and Isopaque showing the geometry of deep groundwater reservoirs and target horizons and thus to define their depthtime and thicknesses-time.

(v) 3D Isochronous Model of Semideep and Deep Aquifers in Oued El Hajel and Ouled Asker Basins. After analyzing the seismic lines, three target aquifers were detected. In order to provide concrete and realistic exploitation results for Oued El Hajel and Ouled Asker deep aquifers, a 3D mapping of these aquifers (first aquifer, second aquifer, and third aquifer) was performed to obtain a general subsurface model of the study area with folded and uplifted zone against collapsed basins forming subsiding synclines interpreted as potential areas of groundwater convergence and accumulation.

(a) The first aquifer consists of a siliciclastic reservoir (Langhian-Serravallian): Ain Grab and Beglia formations (Figure 15).

(b) The second aquifer is a sandstone reservoir (Oligocene-Lower Miocene (Aquitanian)): Fortuna formation (Figure 16).

(c) The third aquifer consists of a carbonate reservoir (Upper Cretaceous: Campanian- Maastrichtian): "Abiod formation," and Eocene: Ypresian "Metlaoui formation" (Figure 17). 


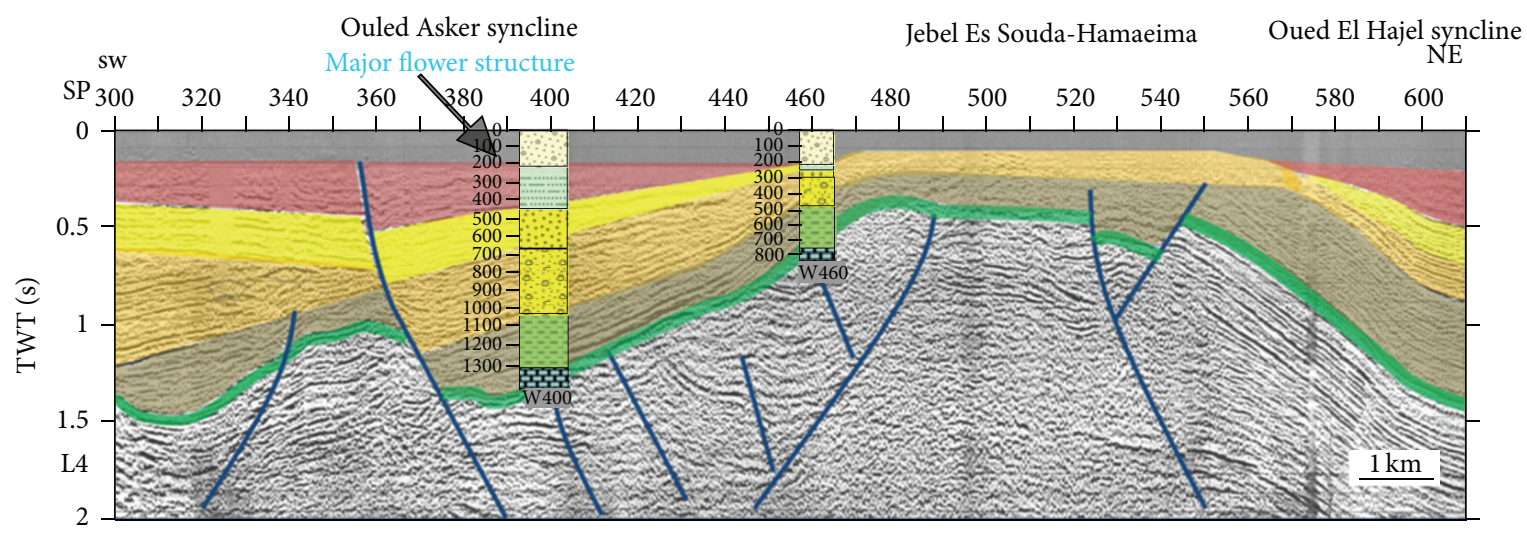

(a)

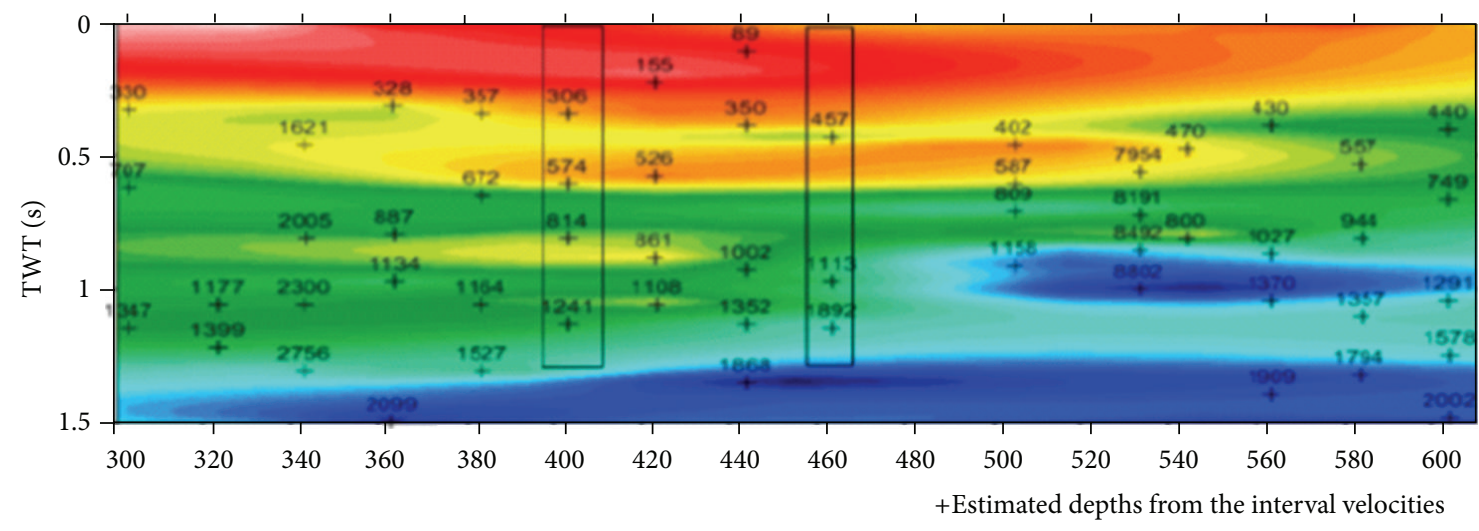

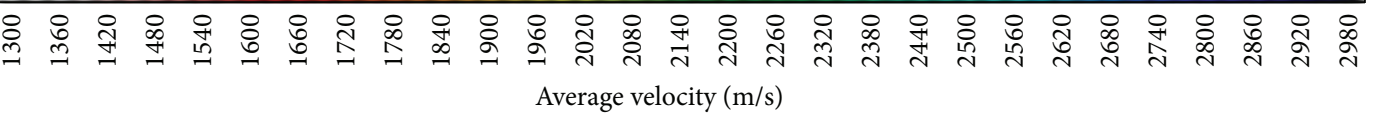

$\begin{array}{ll}\text { Plio-Quaternary } & \text { Oligo-Aquitanian } \\ \text { Upper Miocene } & \text { Middle Eocene-lower Oligocene } \\ \text { Middle Miocene } & \text { Upper Cretaceous-lower Eocene }\end{array}$

(b)

FIGURE 14: (a) W400 and W460 fictive wells associated with the L4 seismic line and (b) average velocity variation associated with L4 (black dashed line frame). (+) Depths estimated from the interval velocities.

\section{Conclusion}

The integration of the geophysical, geologic, stratigraphic, and well data leads to the following.

(i) The geometrical characterization of the Oued El Hajel and Ouled Asker water table with NE-SW, N-S, and E-W lineaments.

(ii) The identification of target aquifers for the hydrogeological prospection which was based on the seismic analysis and interpretation. The obtained results helped in identifying the different units forming the aquifers: limestone levels (Upper Cretaceous to Lower Eocene)-sandstones and sand levels from the Oligo-Miocene to the Mio-Plio-Quaternary. In fact, the study area is mainly formed of (a) large gutter structures characterized by a differential encasement from Oued El Hajel to Ouled Asker,

(b) strait anticlines and an overlapping tendency along the NE-SW à NNE-SSW fault corridors; based on the integration of different geophysical methods, it was possible to conclude that the study area is mainly formed by horst and graben structures, box folds and, also several flower structures with fan-shaped configuration. The latter present an important hydrogeological interest. The study area is also affected by an important faulting system with deep rooted faults that implicated the individualization of depressed area presenting potential zone in which it was possible to suggest a number of fictive wells. 


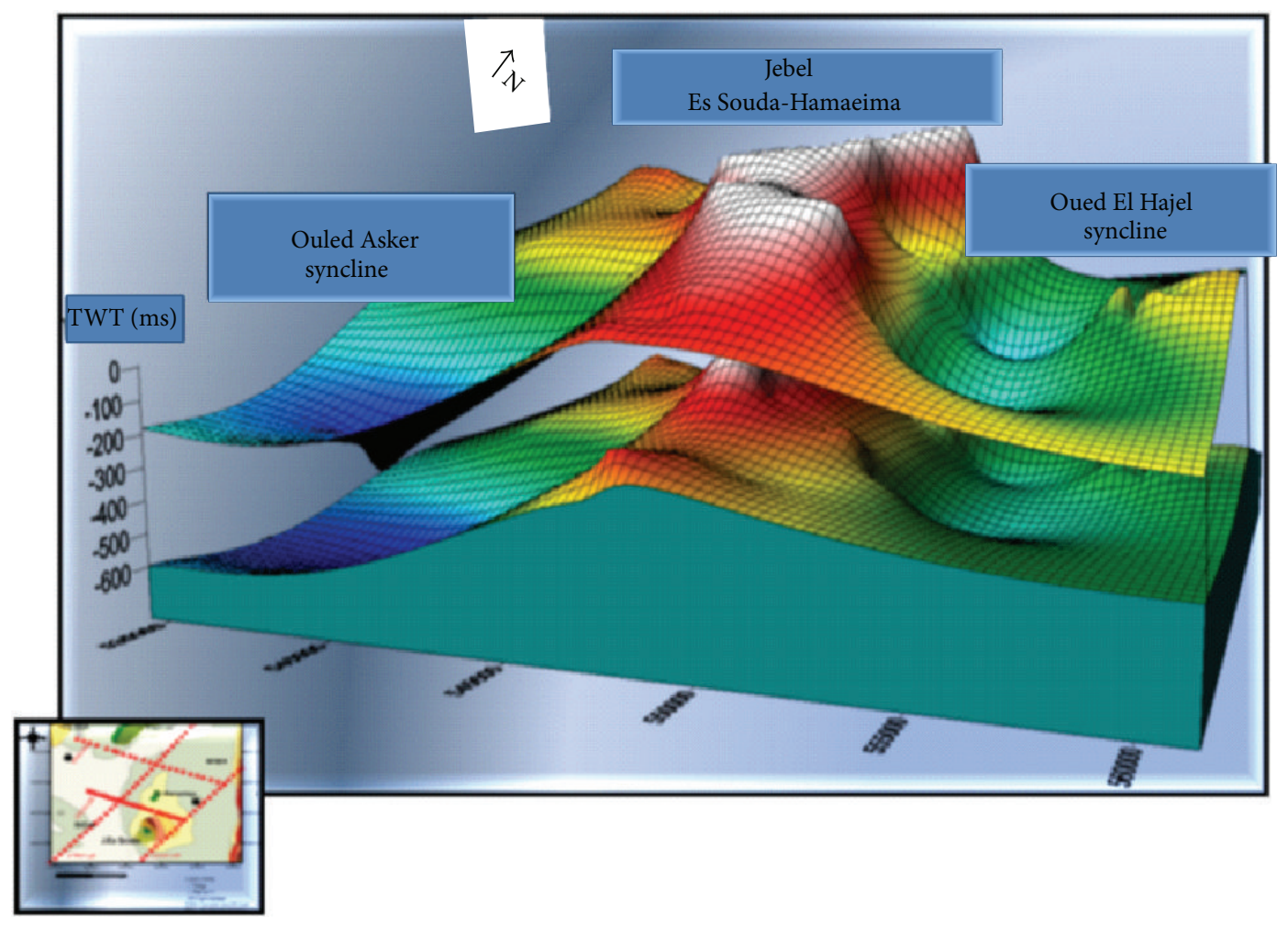

FIGURE 15: 3D visualization of the Langhian-Serravallian (Middle Miocene) reservoir.

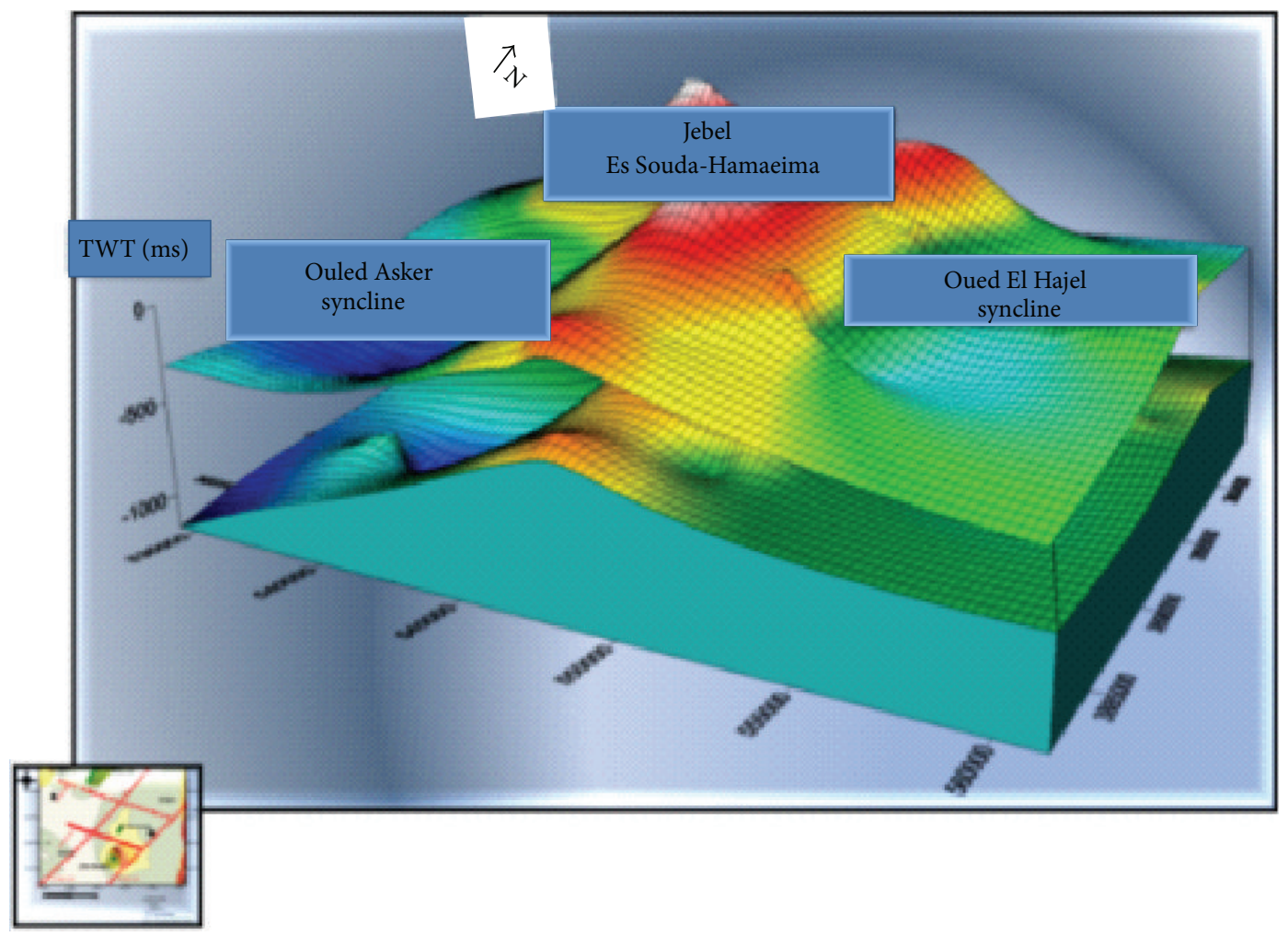

FIGURE 16: 3D visualization of the Oligocene-Aquitanian (Lower Miocene) reservoir. 


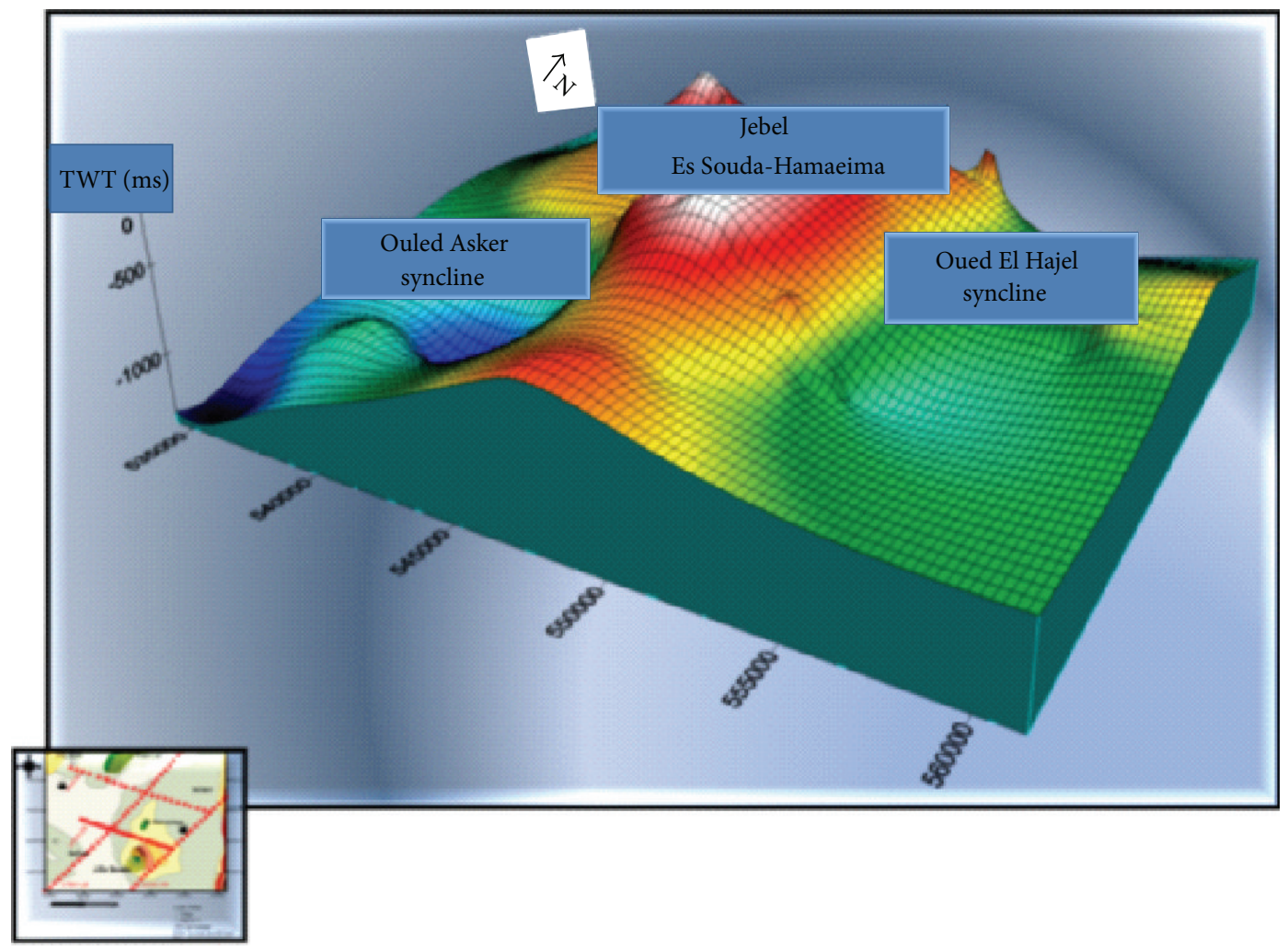

FIGURE 17: 3D visualization of the Upper Cretaceous reservoir.

\section{Conflict of Interests}

The authors declare that there is no conflict of interests regarding the publication of this paper.

\section{Acknowledgments}

The research was supported by Sahel-Kairouanais project (CERTE 2010-2013, resp., Pr. M. Bedir). The authors are very grateful to ONM and ETAP for the scientific supports.

\section{References}

[1] H. Smida, Apports des Systèmes d'Informations Géographiques (SIG) pour une approche intégrée dans l'étude et la gestion des ressources en eau des systèmes aquifères de la région de Sidi Bouzid (Tunisie centrale) [Ph.D. thesis], Université de Sfax, 2008.

[2] P. F. Burollet, Contribution à l'Étude Stratigraphique de la Tunisie Centrale, Annales des Mines et de la Géologie de Tunisie no. 18, 1956.

[3] D. Tanfous, H. Gabtni, H. Azaiez, M. Soussi, and M. Bedir, "Integrated gravity and seismic investigations over the Jebel Es Souda-Hmaeima structure: implication for basement configuration of the eastern frontal fold-and-thrust belt of Tunisian Atlasic Mountains," Arabian Journal of Geosciences, vol. 5, no. 3, pp. 513-524, 2012.

[4] A. Kadri, Evolution Tectonosedimentaire (Aptien-Quaternaire) des DJ. Koumine, Hamra et Lessouda (Tunisie Centrale), Université de Paris-Sud Centre D’Orsay, 1988.
[5] S. Bouaziz, E. Barrier, M. Soussi, M. M. Turki, and H. Zouari, "Tectonic evolution of the northern African margin in Tunisia from paleostress data and sedimentary record," Tectonophysics, vol. 357, no. 1-4, pp. 227-253, 2002.

[6] H. Buness, P. Giese, C. Eva et al., "The EGT'85 seismic experiment in Tunisia: a reconnaissance of the deep structures," in Proceedings of the 6th Workshop on the European Geotraverse Project, Data compilations and synoptic interpretation, R. Freeman and S. Muller, Eds., pp. 197-210, European Science Foundation, Strasbourg, France, 1989.

[7] R. J. Blakely and R. W. Simpson, "Approximating edges of source bodies from magnetic or gravity anomalies," Geophysics, vol. 51, no. 7, pp. 1494-1498, 1986.

[8] A. B. Reid, J. M. Allsop, H. Granser, A. J. Millett, and I. W. Somerton, "Magnetic interpretation in three dimensions using Euler deconvolution," Geophysics, vol. 55, no. 1, pp. 80-91, 1990.

[9] N. Boukadi, Structuration de l'Atlas de Tunisie: signification géométrique et cinématique des noeuds et des zones d'interférences structurales au contact de grands couloirs tectoniques [Thèse d'Etat], Université de Tunis II, Tunis, Tunisia, 1994.

[10] H. Azaïez, H. Gabtni, I. Bouyahya, D. Tanfous, and M. Bédir, "Lineaments extraction from gravity data by automatic lineament tracing method in Sidi Bouzid Basin (Central Tunisia): structural framework inference and hydrogeological implication," International Journal of Geosciences, vol. 2, no. 3, pp. 373$383,2011$.

[11] H. Gabtni, Caractérisation profonde et modélisation géophysique des zones de transition entre les différents blocs structuraux de la Tunisie centro-méridionale [Thèse de Doctorat], Université de Tunis El Manar, 2006. 
[12] C. Doglioni, A. Bosellini, M. C. Frare, F. Dhaha, and E. A. Ben Said, "Aspects tectoniques de la region au sud-ouest de Kairouan (Tunisie centrale)," Estratto da: Annali dell' Università di Ferrara (Nuova Serie). Science Terra, vol. 2, no. 5, pp. 77-94, 1990.

[13] M. Bédir, Mécanismes géodynamiques des bassins associés aux couloirs de coulissement de la marge atlasique de la Tunisie: sismo-stratigraphie, sismo-tectonique et implications pétrolières [Thèse de Doctorat es Sciences], Université de Tunis, 1995.

[14] A. Hlaiem, "Halokinesis and structural evolution of the major features in eastern and southern Tunisian Atlas," Tectonophysics, vol. 306, no. 1, pp. 79-95, 1999.

[15] T. Zouaghi, Distribution des séquences de dépôt du Crétacé (Aptien-Maastrichtien) en subsurface: rôle de la déformation tectonique, l'halocinèse et évolution géodynamique (Atlas central de Tunisie) [Thèse Doctorat], Université de Tunis El Manar, 2008.

[16] M. Ben Haj Ali, M. Jedoui, T. Dali, H. Ben Salem, and L. Memmi, "Geology map of Tunisia, Office National des Mines (ONM publication)," 3 Sheets, Scale 1: 500.000, Département de Géologie, Tunis, Tunisie, 1985.

[17] G. Creuzot and J. Ouali, "Extension, diapirisme et compression en Tunisie Centrale. Le Jebel Es Souda," Géodynamique, vol. 4, no. 1, pp. 39-48, 1989. 

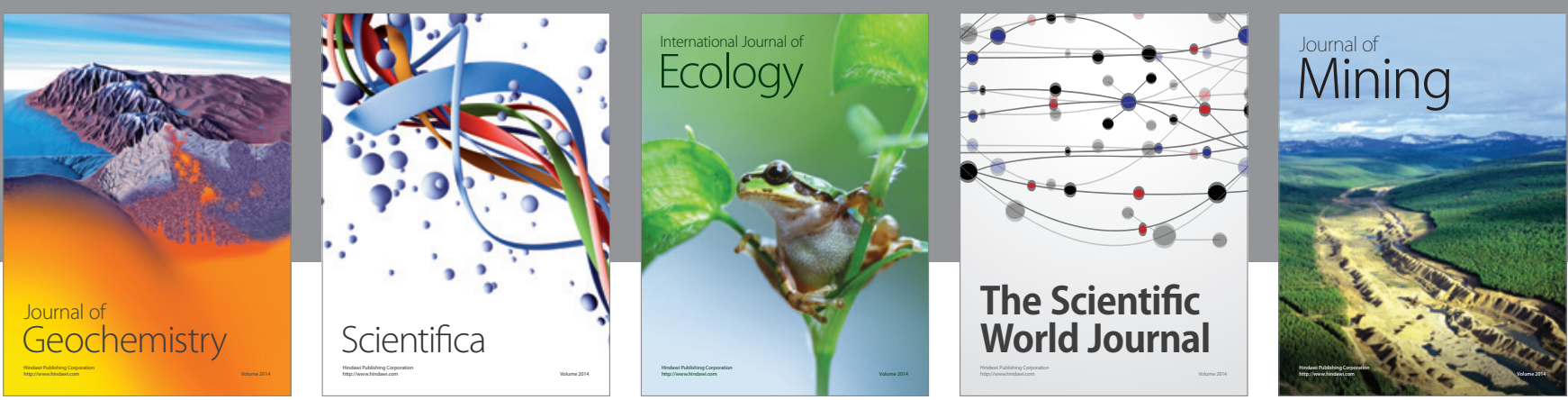

The Scientific World Journal
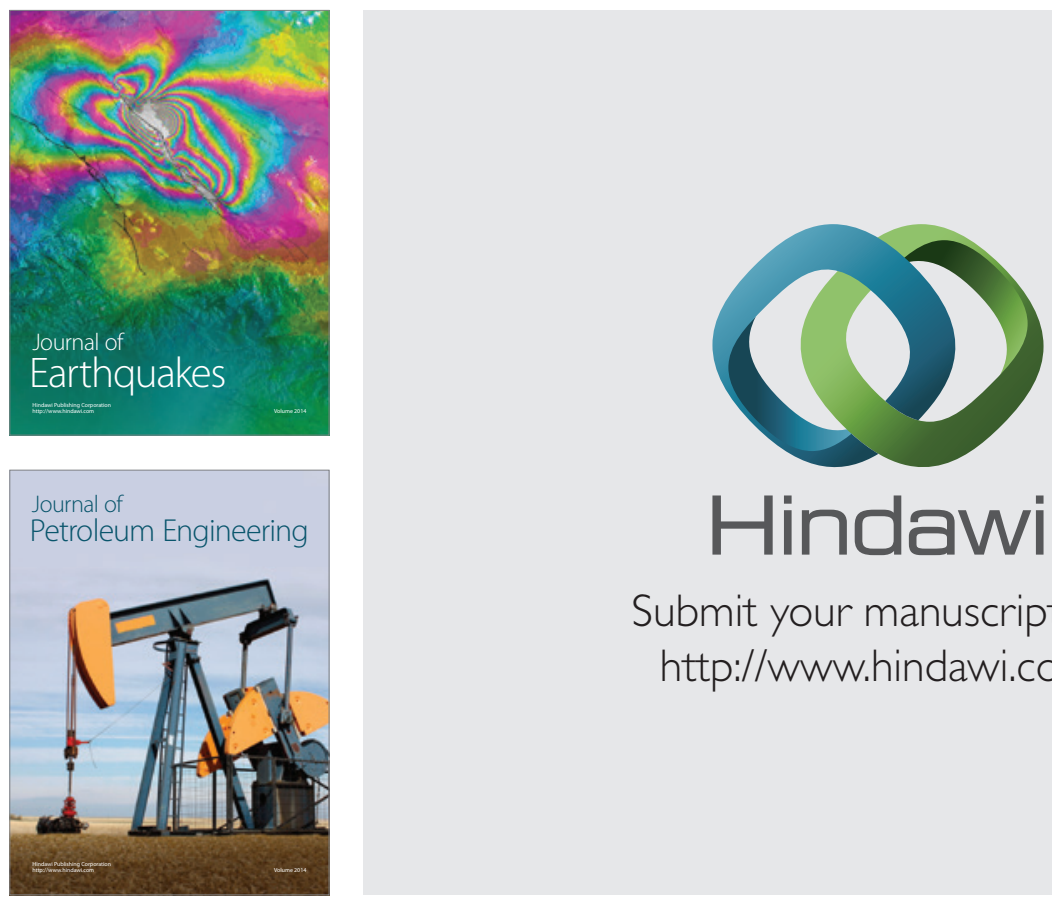

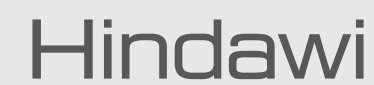

Submit your manuscripts at

http://www.hindawi.com
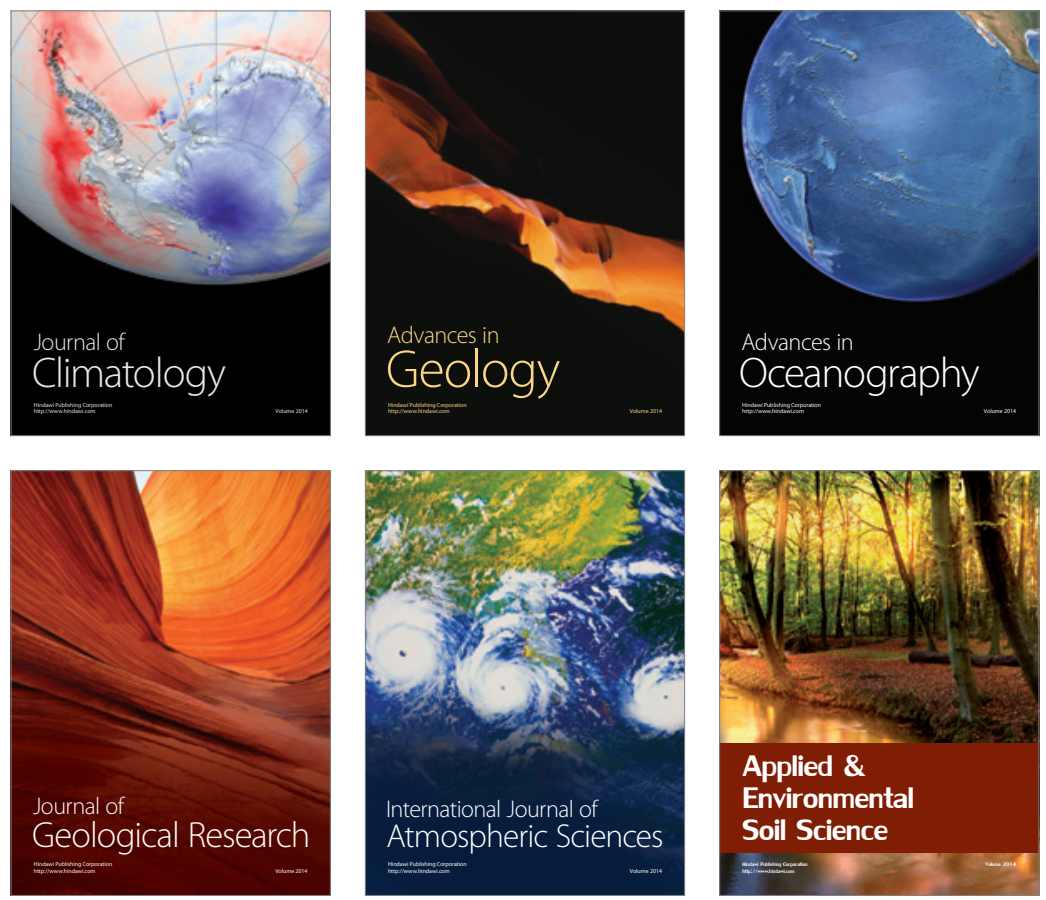
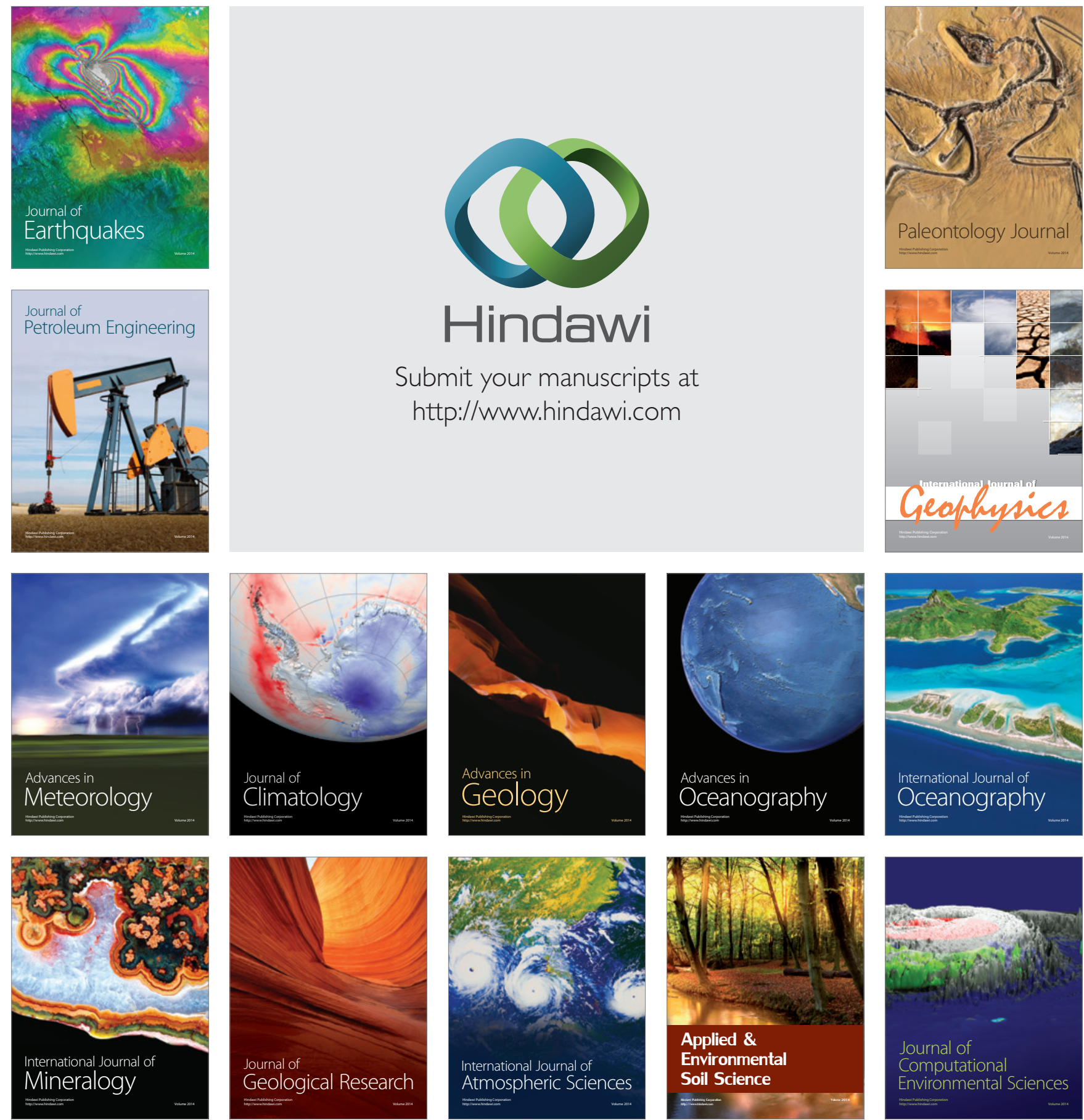